\title{
AN ATTEMPT TO INTEGRATION OF DIFFERENT GEOPHYSICAL METHODS (MAGNETIC, GPR AND ERT); A CASE STUDY FROM THE LATE ROMAN SETTLEMENT ON THE ISLAND OF RAB IN CROATIA
}

\author{
Fabian Welc ${ }^{1}$, Radosław Mieszkowski², Goranka Lipovac Vrkljan ${ }^{3}$, Ana Konestra ${ }^{3}$ \\ ${ }^{1}$ Institute of Archaeology, Cardinal Stefan Wyszyński University, Warsaw,Poland,f.welc@uksw.edu.pl \\ ${ }^{2}$ Faculty of Geology, University of Warsaw, Poland, rngeo@interia.pl \\ ${ }^{3}$ Institute of Archaeology,Zagreb,Croatia,gorankalv@gmail.com,ana.konestra@iarh.hr
}

\begin{abstract}
In 2016 within the RED Project Roman Economy in Dalmatia: production, distribution and demand in the light of pottery workshops, 5 selected areas around the Podšilo Bay were geophysically surveyed. During the fieldworks in the Lopar protected area, located in the northeastern part of the Island of Rab a gradiometer, ground-penetrating radar (GPR) and electrical resistivity tomography (ERT) were used. The main aim of the project was to document presence of the Roman architecture in two areas of the bay's hinterland as suggested earlier by finds of pottery and glass. Geophysical studies conducted in the Lopar area revealed presence of underground remains of ancient structures, probably from the late Roman period and connected with a ceramic production centre at the present seashore. The most interesting results were obtained for the area no. 4, the site where magnetic, georadar and ERT surveys revealed an ancient regular building at $0.4-0.6 \mathrm{~m}$ depth. The survey performed in the Lopar area clearly indicates that integration of different geophysical methods enables detailed and effective identification of buried archaeological structures.
\end{abstract}

Key words: archaeological geophysics, Roman structures, magnetic method, GPR, ERT, Lopar, Croatia

Manuscript received 20 December 2016, accepted 8 April 2017

\section{INTRODUCTION}

The techniques of geophysical prospection were initially designated for geology (Weymouth, 1986; Scollar et al., 1990), but at present they are also widely and successfully used in archaeology. While many new geophysical methods have been developed recently, three of them are principally employed in archaeological surveys including electrical resistivity (nowadays electrical resistivity tomography ERT is more and more popular), magnetometry and ground-penetrating radar (GPR) (Coneyers and Leckebusch, 2010). In fact, none of these methods is universal for archaeology (see more in: Milsom, 2003; Owsin, 2009; Toushmalani, 2010) and for this reason these techniques should be applied as complementary to one another. The archaeological geophysics seems currently to move to the next stage of its development, which is an attempt to integrate different geophysical methods within a single survey or project (Keay et al., 2009; Conyers, 2016).

A number of archaeological surveys integrating GPR, magnetic and ERT methods is systematically increasing (see among others; Brizzolari et al., 1992; Neubauer and Eder-Hinterleitner, 1997, 1997a; Drahor and Kaya, 2000; Piro et al., 2000; Gaffney et al., 2004; Luck et al., 2003; De Domenico et al., 2006; Drahor, 2006; Kvamme, 2006; Vermeulen et al., 2006; Strutt and Keay, 2008; Drahor et al., 2009; Cardarelli and Di Filippo, 2009; Keay et al., 2009; Leucci et al., 2015; Di Maio et al., 2016). In this paper we present results of research based on integration of three basic geophysical methods (magnetic, GPR and ERT) carried out at Lopar in the northern part of the Island of $\mathrm{Rab}$ in Croatia. They illustrate of benefits of a non-invasive approach to archaeological investigation.

\section{STUDY AREA AND GEOLOGICAL SETTING}

The Island of Rab is located just off the northern Croatian coast in the Adriatic Sea and occupies an area of $93.6 \mathrm{~km}^{2}$ (Fig. 1). The north-eastern part of the island is barren and a karst area, while the south-western part is covered by a dense oak forest. Rab was mentioned for the first 


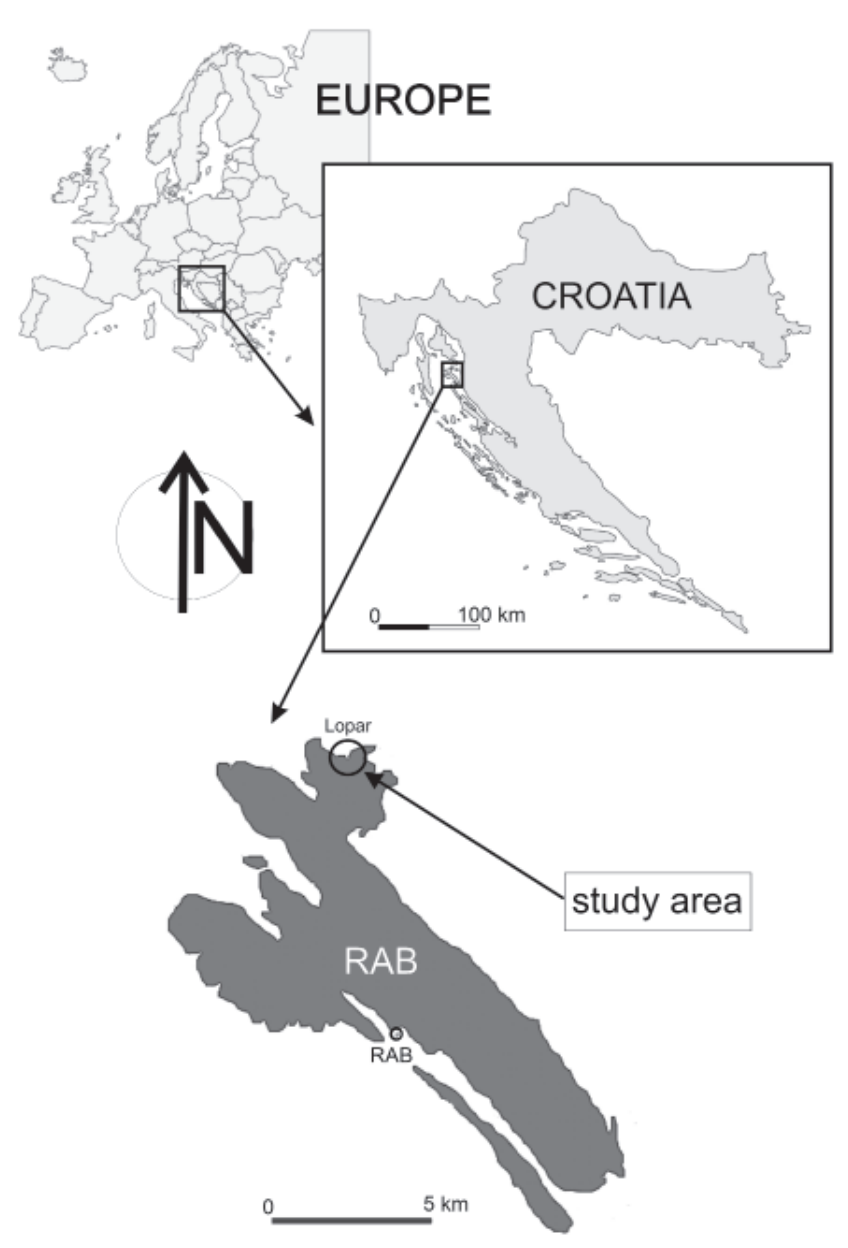

Fig. 1. Location sketch of the Island of Rab and the Lopar area.

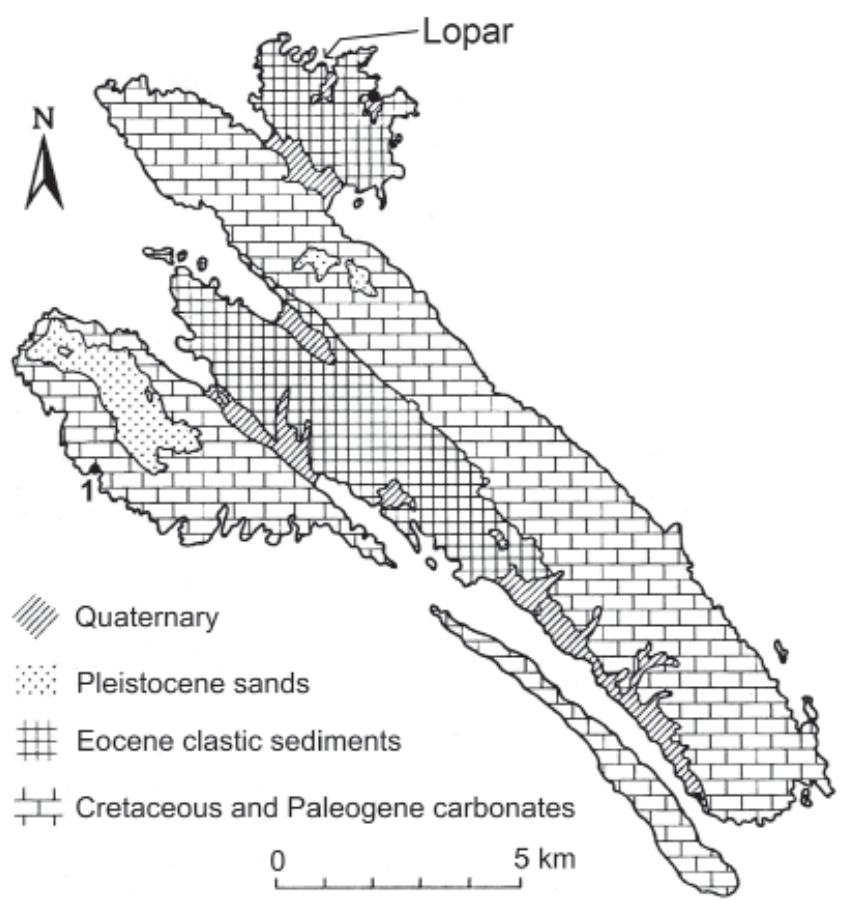

Fig. 2. Sketch geological map of the Island of Rab after Mamuzić et al. (1969). time in the Periplus of Pseudo Scylax (ca. 360 yrs BC) and later by Greek and Roman geographers with the name of Arba/Arva. The earliest finds on the island occurring near Lopar are dated to the late Paleolithic. In the Bronze Age the island was inhabited by humans of the Kvarner group and in the Iron Age by Liburnians. A Roman rule spread on the island during the 1st century BC as testified by inscriptions found in the town of Rab. Most of the island was covered by Roman rural settlements, remains of which have not been studied and mapped yet (see Malez, 1987; Jurković et al., 2012; Lipovac and Šiljeg, 2012; Lipovac and Konestra, 2015).

From a geological point of view, the Island of Rab belongs to the External Dinarides or the Adriatic carbonate platform (Vlahović et al., 2005) (Fig. 2). Geology of the island is relatively simple, with 2 anticlines and 2 synclines. Cretaceous carbonate rocks are the oldest outcrops and they are overlain uncomfortably by Eocene carbonates referred to as a 'flysch' (Marjanac and Marjanac, 1991, 2007). Eocene clastics comprise an older unit, which is a marlysandy formation and a younger one referred to as the Lopar Sandstones. In the Lopar area, the youngest Quaternary deposits are mostly the reddish-brown sands, which are described as the 'Quaternary diluvium' (slope deposits) and overlie uncomfortably the Lopar Sandstones (Mamuzić et al., 1969; Marjanc and Marjanac, 2016) (Fig. 2).

In the near-shore part of the Lopar area (Figs 3, 4) the subsurface layers, both of natural and anthropogenic origin are exposed almost always in a secondary (disturbed) context, which is evidenced e.g. by numerous ceramic fragments and other traces of human activity visible in natural exposures. The material seems to be relocated and mixed, what suggests that slope processes initiated in the past are still active.

A shallow geological drilling carried out in the central part of the site no. 4 (Lopar 1) revealed the following arrangement of geological and anthropogenic layers (Figs 2, 5): $0.00-0.05 \mathrm{~m}$ soil with high contents of organic material, $0.05-0.25 \mathrm{~m}$ medium-grained silty sand, brown color,

0.25-0.60 m anthropogenic (archaeological) layer: fragments of limestone mortar, ceramics, loam and charcoal,

0.60-1.00 m clayey vari-grained sand, brown color.

Two drillings were located in the center of a neighboring area no. 5. The log Lopar 2 presents the following sequence (Figs 2, 5):

$0.00-0.10 \mathrm{~m}$ sandy soil,

0.10-0.70 m anthropogenic (archaeological) layer: coarsegrained sand with silt, fragments of limestone mortar, charcoal and ceramics fragments,

0.70-1.00 m coarse-grained sand with silt, brown color.

A log of the drilling located in the northern part of the area is as follows: $0.00-0.05 \mathrm{~m}$ soil, $0.05-0.50 \mathrm{~m}$ coarse-grained sand, Fe precipitates at $0.45 \mathrm{~m}$, $0.50-1.00 \mathrm{~m}$ sand with silt, brown. 


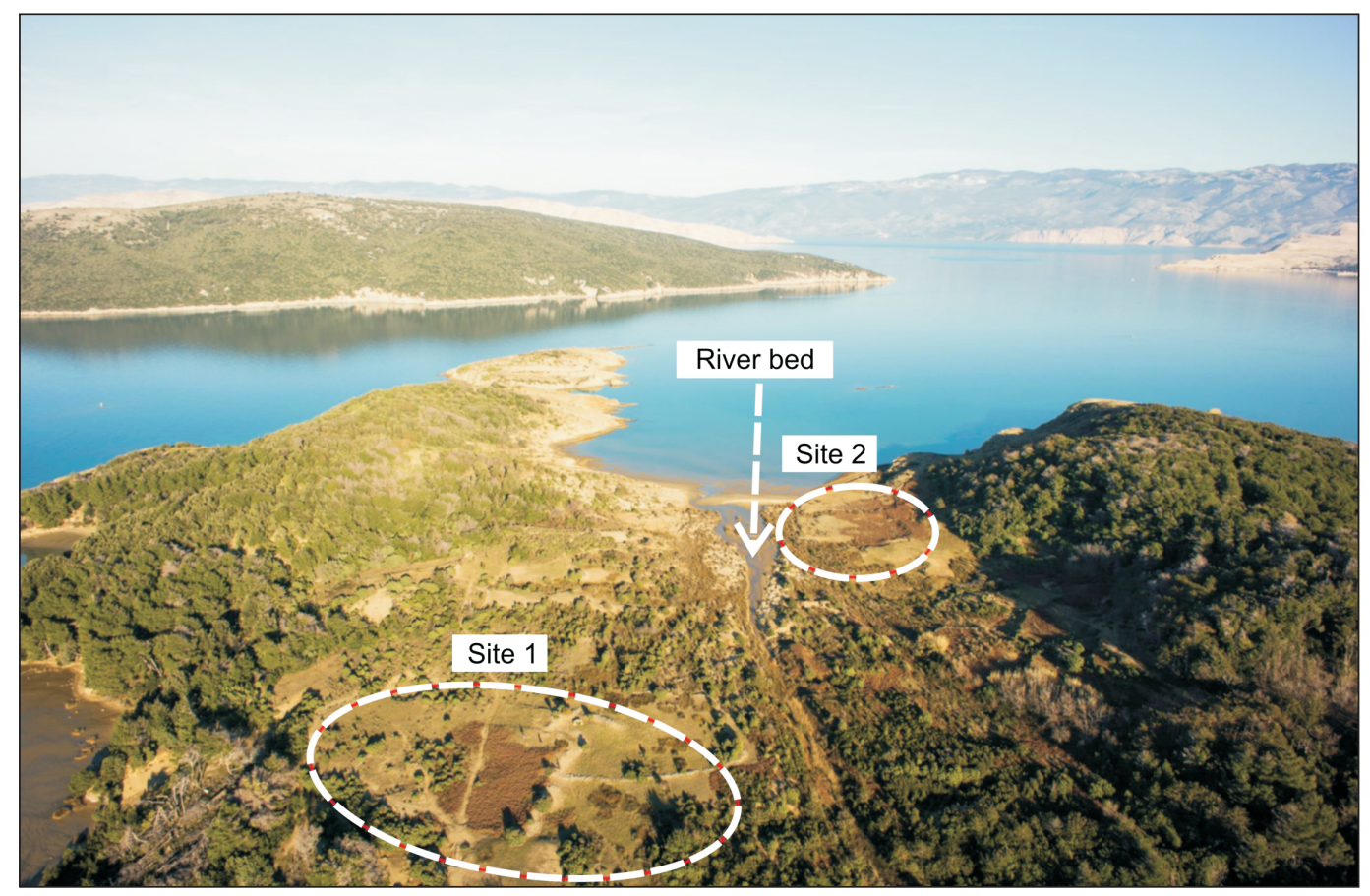

$\longleftarrow$ North

Site 2

Site 1
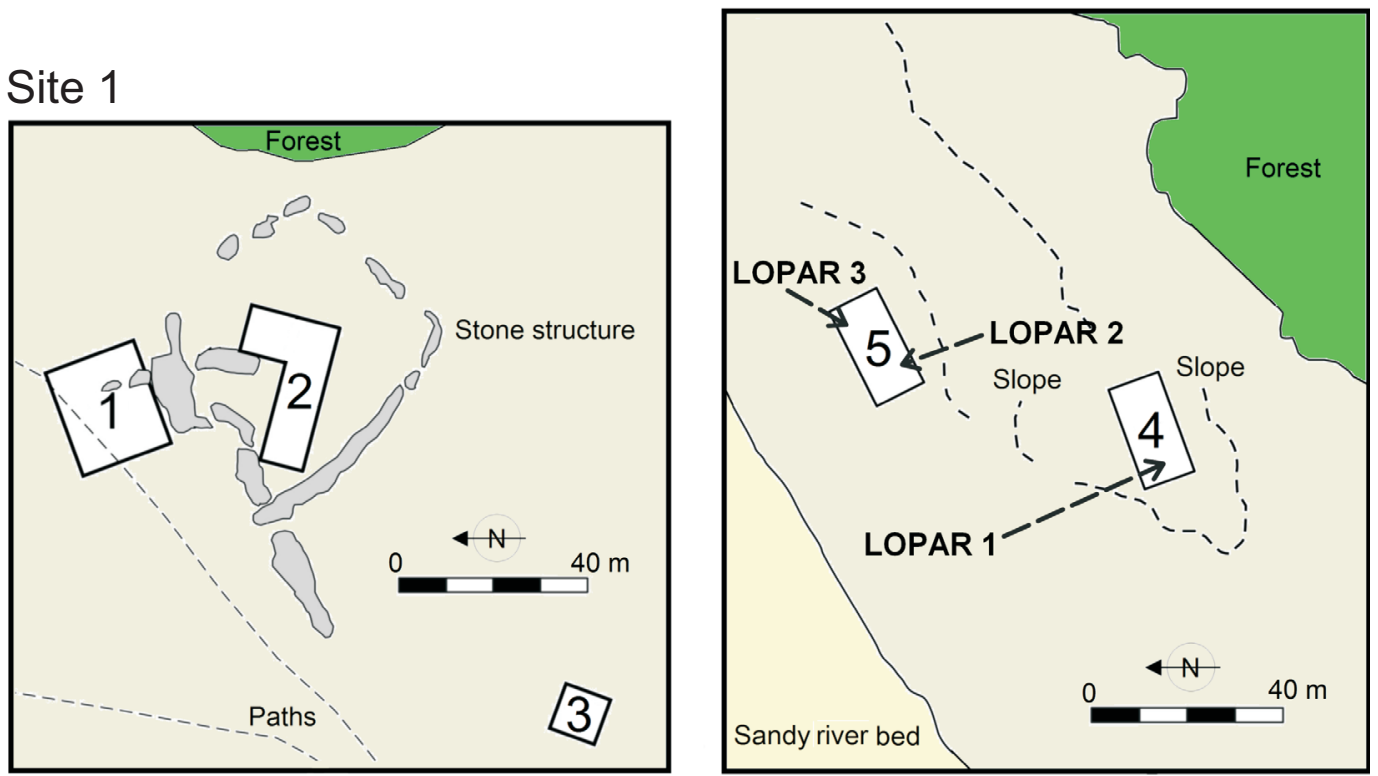

Fig. 3. General view of the Lopar area in the north-eastern part of the Island of Rab and location (below) of the examined areas nos. 1-5, including drillings LOPAR 1-3.

Geology of the studied area influenced final results of geophysical measurements. The shallow layer with archaeological remains and its composition, which produced a strong contrast between iron-rich magnetic sands and non-magnetic limestone debris, was undoubtedly conducive for a magnetic survey. In case of GPR measurments, the anthropogenic layers filled with limestone debris create high amplitude pointsource reflections from individual limestone clasts, which are readily distinguished in reflection profiles. However, in case of the studied area, the archaeological horizon is overlain by a thick clayey soil, creating a variable environment that affected propagation of radar energy.

\section{MAIN AIM OF GEOPHYSICAL RESEARCH IN THE LOPAR AREA}

In 2013 the Archaeological Topography of the Rab Island Project headed by Goranka Lipovac Vrkljan was initiated in collaboration with the Conservation Department in Rijeka. The first phase of the project focused mainly on the territory of the Lopar municipality, which is located in the northern part of the Island (Fig. 1), where the Institute of Archaeology from Zagreb had already made some discoveries, among others in the Roman pottery kiln located in the Podšilo Bay (Lipovac and Šiljeg, 2012). 

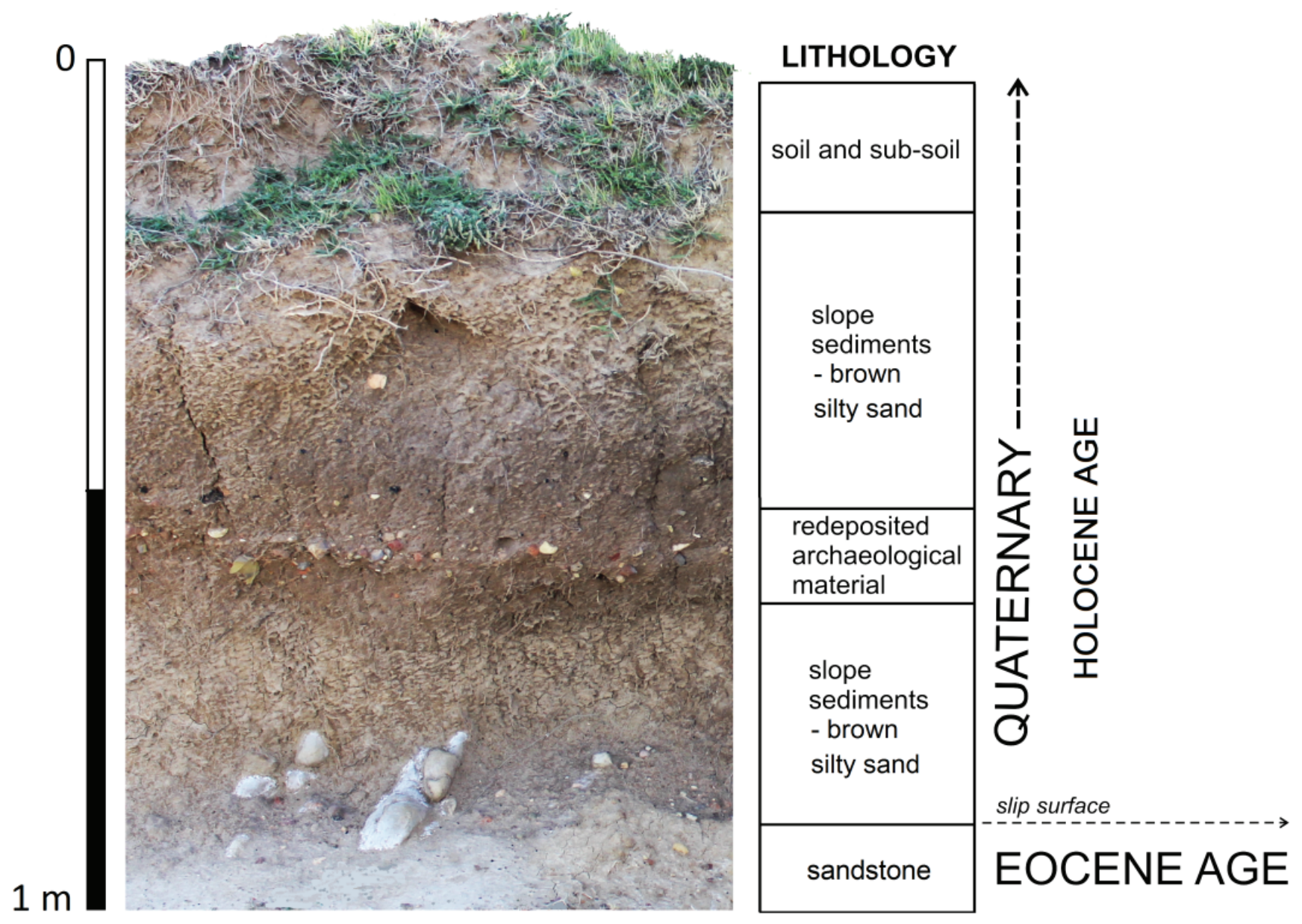

Fig. 4. Natural exposure located at Lopar presenting geology of the site.

In 2016 within the RED Project (Roman Economy in Dalmatia: production, distribution and demand in the light of pottery workshops) funded by the Croatian Science Foundation (IP-11-2013-3973) the Podšilo Bay was geophysically surveyed in selected areas (1 to 5). Institute of Archaeology of Cardinal Stefan Wyszyński University in Warsaw conducted the survey.

The main aim of the project was to document the Roman architecture in two areas in the bay hinterland, presence of which was suggested by pottery and glass finds (Lipovac et al., 2014). In the central part of Lopar there is a site with extensive and mysterious stone structure, which has not been dated due to re-used of its construction material (Figs 3, $6-7)$. Based on pottery findings the so-called stone structure can be only tentatively dated to the late Roman period. A primary aim of the survey was to determine whether there were other remains of ancient architecture that do not occur on the land surface. The results could then support a thesis on presence of buildings and other structures at the site, which could belong to the unknown Late Antiquity farming and workshop centre located in the northern part of the Island of Rab. These structures could be connected to pottery klins discovered on the northern shore of the Lopar Bay (Lipovac and Šiljeg, 2012; Lipovac et al., 2015).

\section{METHODOLOGY}

During fieldworks in the Lopar protected area a gradiometer, ground-penetrating radar (GPR) and Electrical Resistivity Tomography (ERT) were used. GPR is a mobile and highly effective method of surface geophysical prospection, based on electromagnetic waves with high and ultra-high frequency. The waves are emitted by a specific device (transmitting-receiver antenna and steering device) and registration of impulses reflected by geological beds and lithological boundaries of varied specific electrical permittivity are recorded (Conyers, 2010, 2013, 2016). A range of GPR prospection depends on nominal frequency of a transmitting antenna and electrical resistivity of the studied geological strata. A lower antenna frequency results in larger penetration depth but lower resolution and in turn, higher electrical resistivity of a geological medium results in smaller depth recognition. In highly unfavorable conditions including low-resistivity deposits (mud, silt or clay), damping of electromagnetic waves may be high enough to decrease a prospection depth from several meters to a dozen centimeters.

The radar system RAMAC produced by the Swedish company Mala Geoscience was used during the survey on 
SW

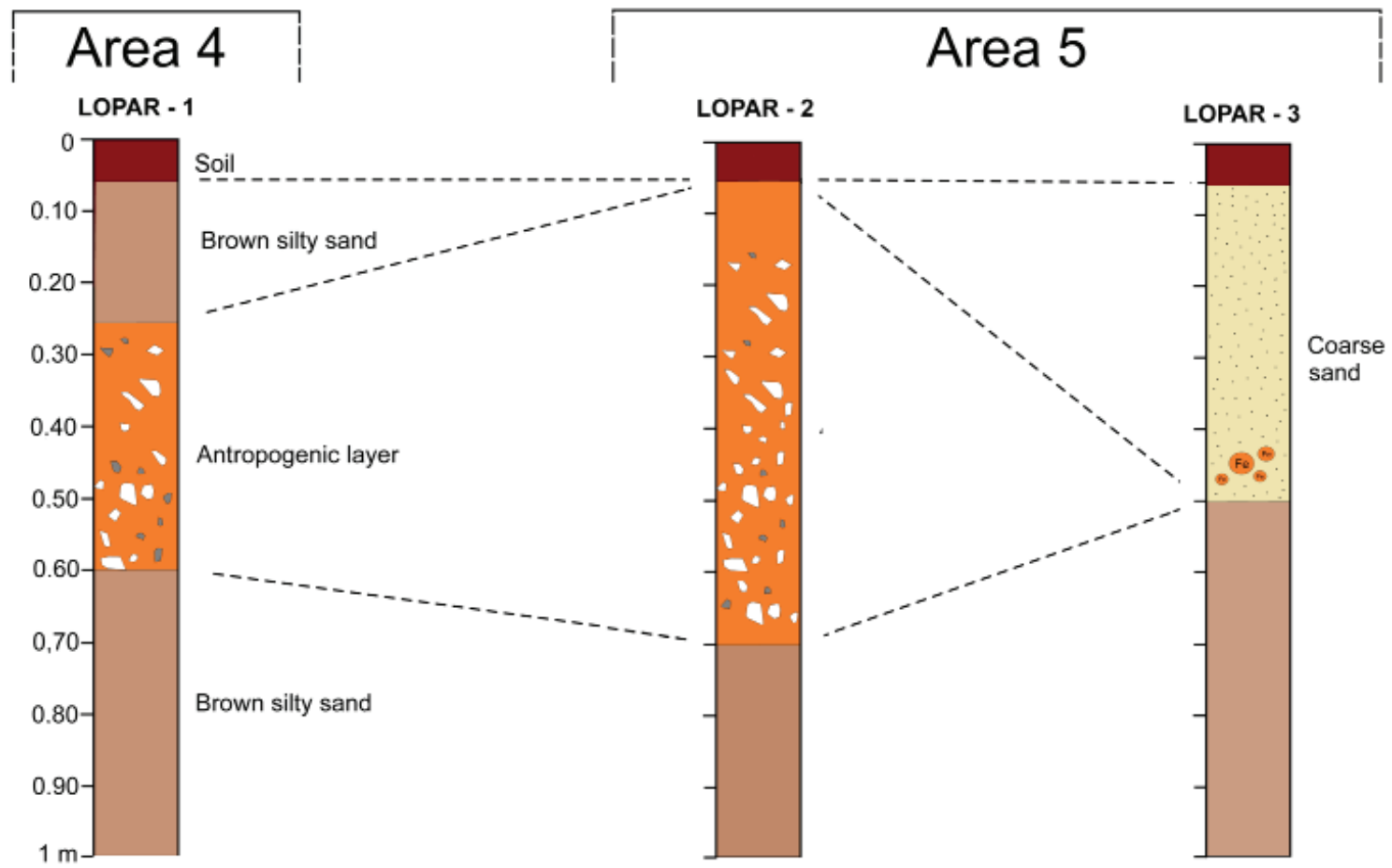

Fig. 5. Logs of shallow geological drillings carried out in the eastern part of the Lopar site in the areas nos. 4 and 5 (for location see Fig. 3 ).

the Island of Rab. The prospection was carried out with application of a shielded transmitting antenna with nominal frequency of the emitted EM wave at $500 \mathrm{MHz}$. The device was equipped with a computer using Ground Vision software designed for acquisition of measurement data directly in the field. All obtained wavegrams were in then processed using a professional GPR software, Reflex-Win of the German company Sendmeier Software and other GPR programs like GPR Process and GPR Viewer (Conyers, 2013). All profiles were processed using standard running average background removal filters, Dewow, DC shift adjustments, manual grain adjustments and various bandpass frequency filtering. In some profiles deconvolution, F-k filtration and migration processing were applied. To create amplitude maps (slices) GPR process software was used (Conyers, 2013, 2016a). The profiles were at $0.5 \mathrm{~m}$ distance from one another.

Electrical resistivity tomography (ERT) is a geophysical technique for searching and imaging sub-surface structures based on electrical resistivity measurements made at the surface using sets of metal electrodes (Hermana, 2001). Assumptions of the electrical resistivity method were formulated in the early 1900 s by the Schlumberger brothers, Conrad and Marcel. A description of the theoretical background was published by Keller and Frischknecht (1966), Sasaki (1992), Zhdanov and Keller (1994), Loke and Barker (1996) and many others.

For a long time the electrical resistivity has been commonly applied during geological and archaeological surveying (Mol and Preston, 2010). Such surveys can be carried out with a constant traverse spacing (electrical profiling) and vertical electrical soundings. More recent surveys have highlighted a vertical component, using pseudosections or tomography. The ERT surveys rely on a theory that with expanding probes, the data are recorded from a greater depth. Complex switching systems control along lines of electrodes and the resulting data provide a vertical section through the ground. These lines can generate 3D image of subsurface structures (Toushmalani, 2010). The ERT method is very useful for detecting walls, cavities and many other structures located at different depth (Thacker and Ellwood, 2002; Gaffney, 2008; Leucci and Greco, 2012). Applications of 3D tomography is therefore more and more important for visualizing and interpreting complex archaeological structures, because vertical range of this method is a great advantage (Drahor et al., 2007; Papadopoulos et al., 2011, 2014; Cozzolino et al., 2012; Leucci and Greco, 2012).

During fieldworks on the Rab Island, the Terrameter LS device of the Swedish company ABEM was used: an eight-channel device furnished with 41-steel electrodes. ERT measurements were made using a gradient protocol. In the survey the electrodes were placed at every 0.75 and $1 \mathrm{~m}$. Such distribution allowed recognizing electrical resistivity of a basement to a depth of about 5-7 m. Measured electrical data were inverted using the interpretation software Res2DINV, implying a non-linear least-squares optimisation technique to obtain inversion of a measured resistivity (Griffiths and Barker, 1993). A topographic correction was taken into account in all profiles. 


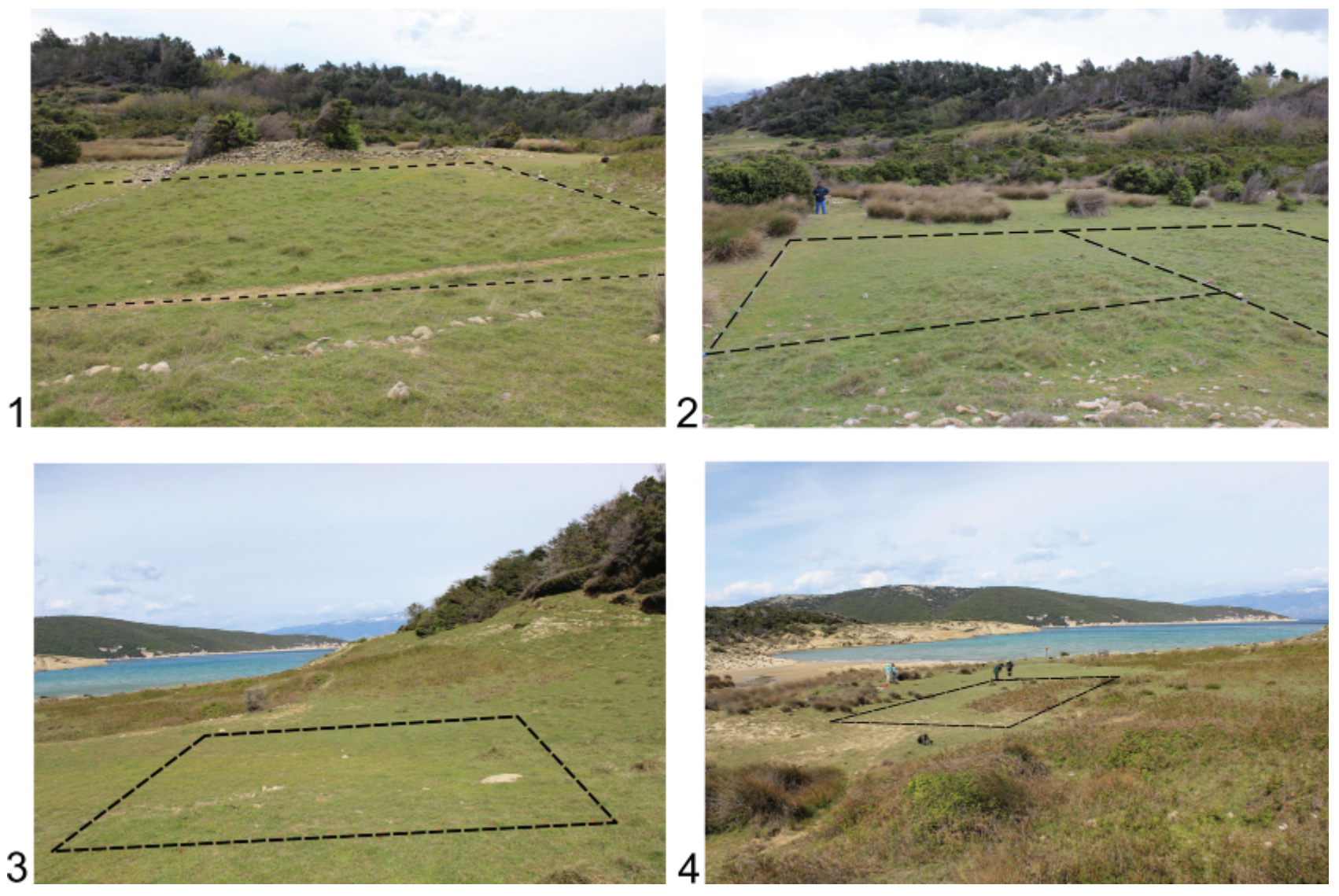

Fig. 6. Areas examined with magnetic, GPR and ERT at Lopar. 1 - site no. 1, area no. 1;2 - site no. 1, area no. 2; 3 - site no. 2, area no. 4; 4 - site no. 2 , area no. 5 .

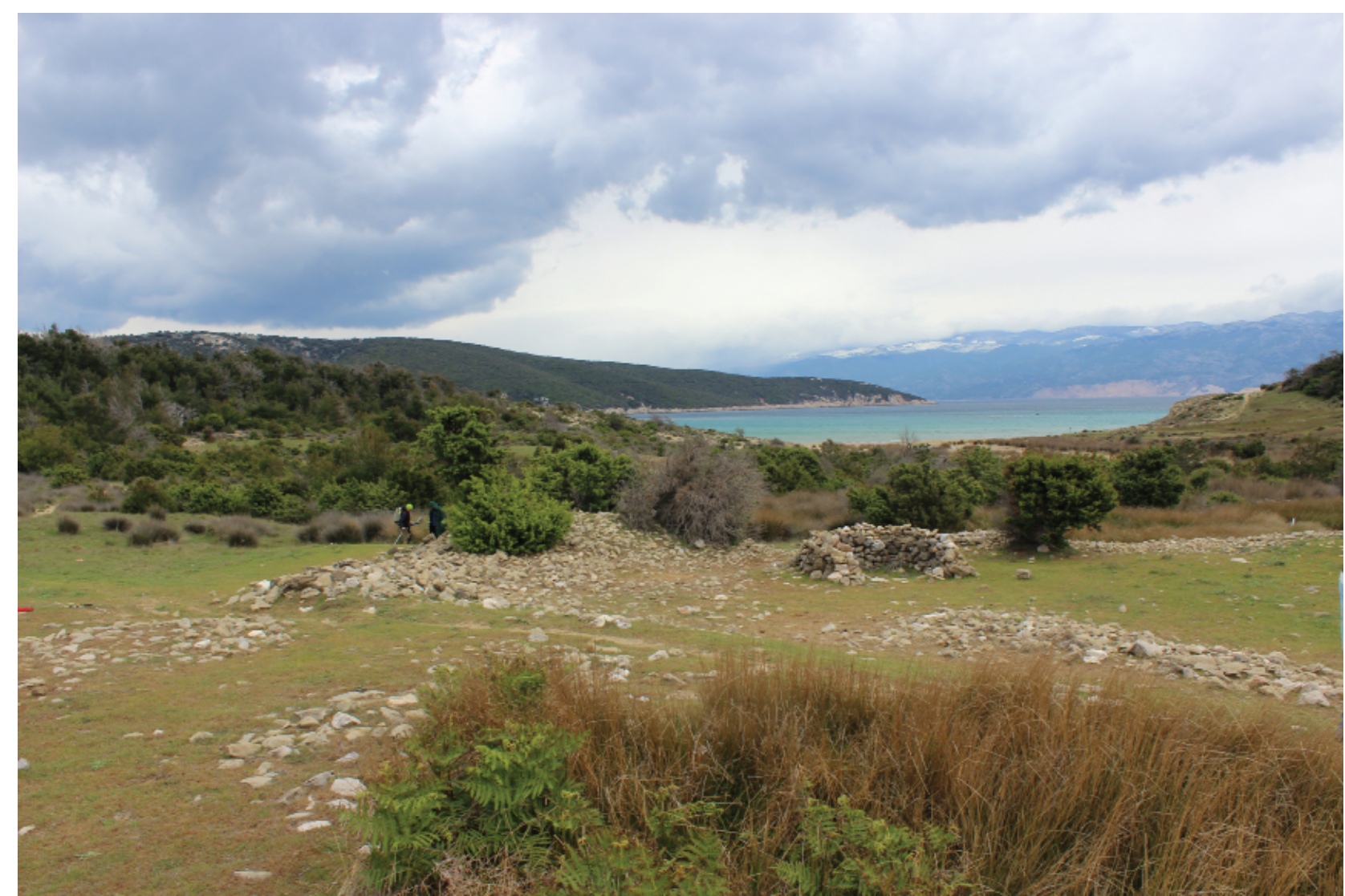

Fig. 7. A stone structure, viewed from the south. 


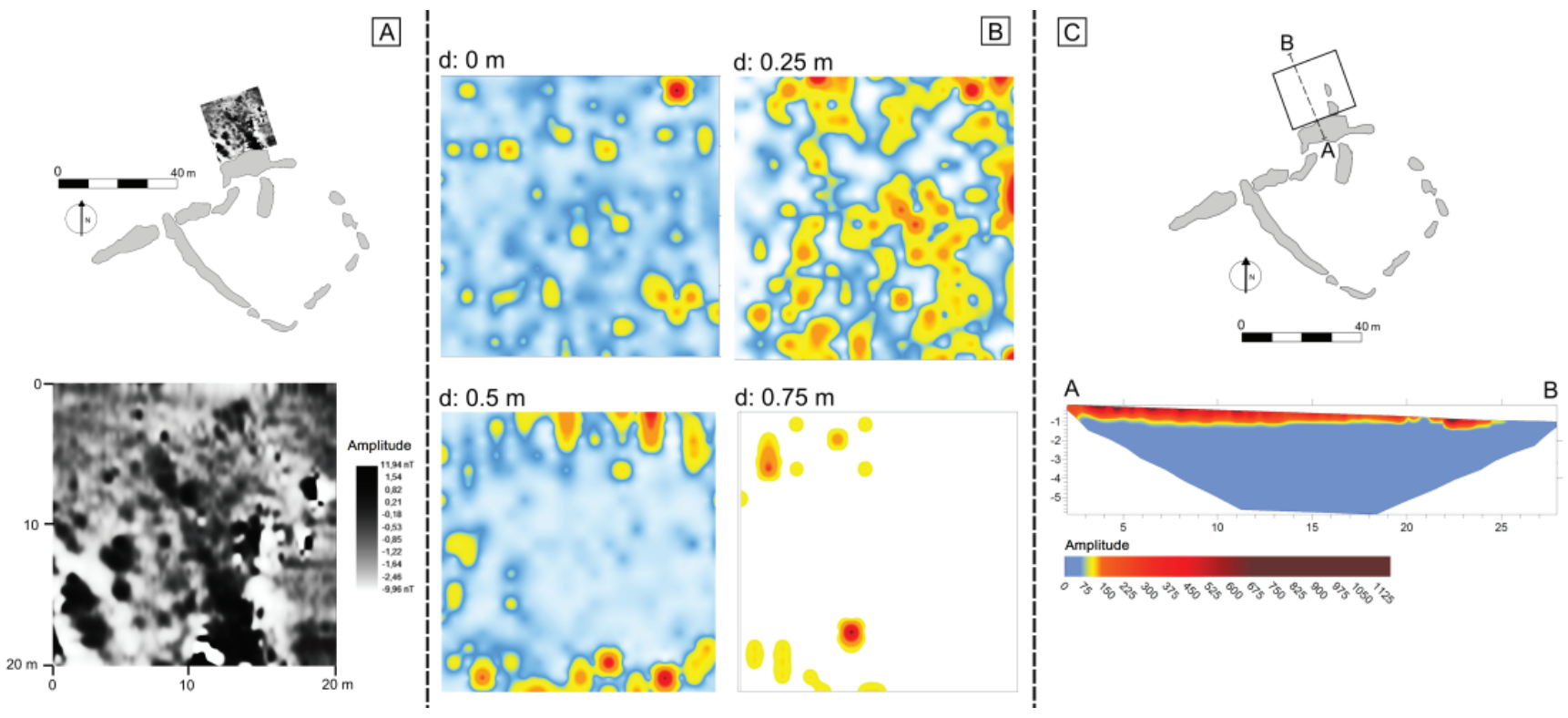

Fig. 8. Results of a geophysical survey at the site no. 1, area no. 1. A - magnetic survey, B - GPR, C - ERT.

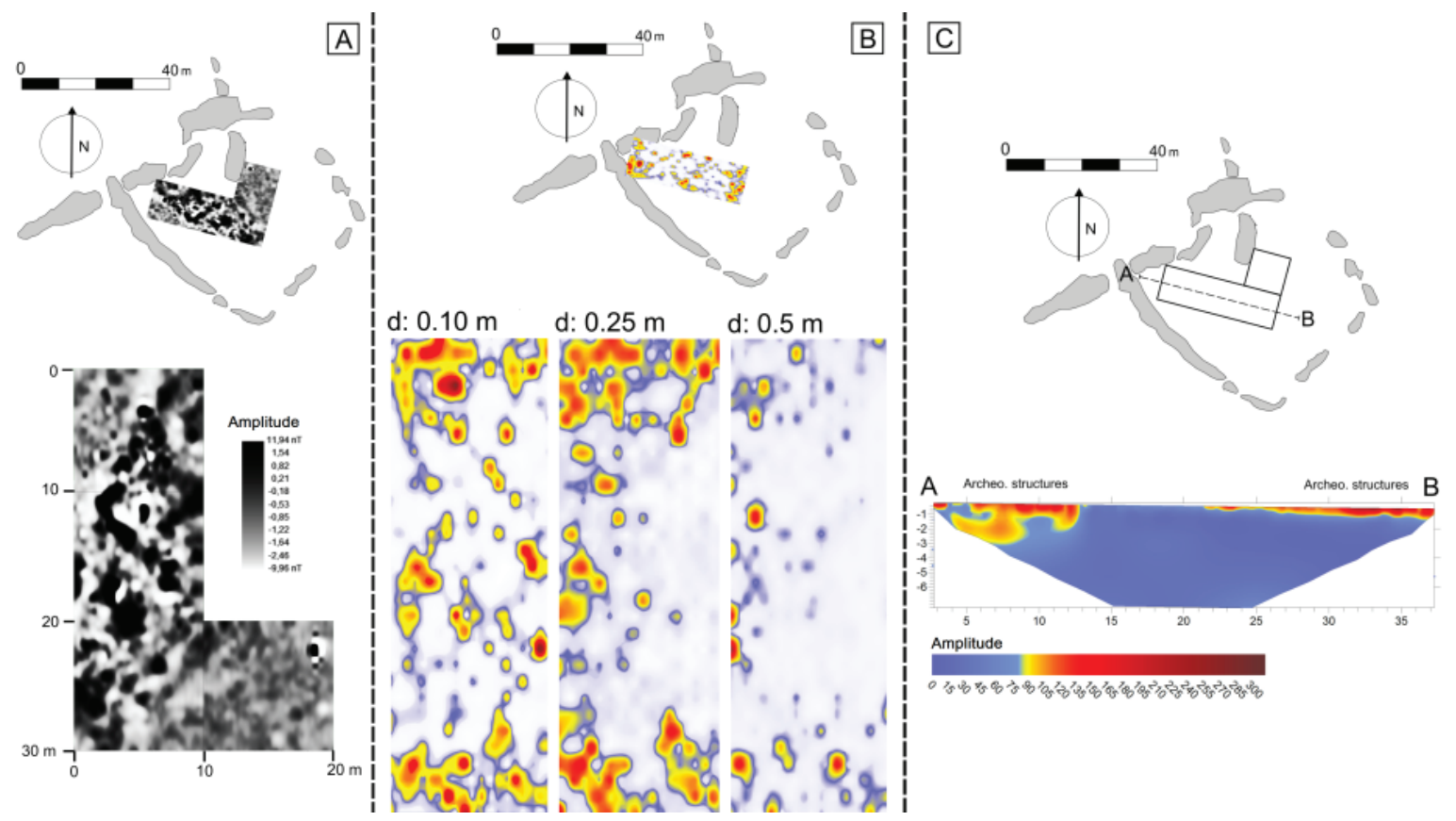

Fig. 9. Results of the geophysical survey at the site no. 2, area no. 1. A-magnetic, B - GPR, C-ERT.

In contrast to the ERT method, a magnetometer surveying is used to detect changes in the Earth's magnetic field caused by concentrations of ferrous minerals in the ground (Won and Huang, 2004). During such surveys, different magnetic properties of soils, rock and archaeological features are recorded as variations against a background magnetic value. Magnetometer surveys are generally suitable for identification of former settlement areas and such archaeological features as hearths, kilns, furnaces, pits, trenches and walls (Gaffney et al., 2000; Herwanger et al., 2000; Herbich, 2003, 2012; Kattenberg and Aalbersberg, 2004; Aspinall et al., 2008; Gaffney, 2008; Jordan, 2009;
Fassbinder, 2015). Changes in a magnetic field connected with archaeological features are usually very weak and produce anomalies which can be measured from 0.2 nanoTesla (nT), in comparison to overall magnetic field strength of 48000 nT (Toushmalani, 2010).

In a course of geophysical activities on the Island of Rab, the Grad601 gradiometer of the British company Bartington was used. The Grad 601 is a fluxgate type gradiometer used to measure variations of a magnetic field that are caused by buried anomalies. The system comprises a data logger, which works within grids of $10 \times 10 \mathrm{~m}, 20 \times$ $20 \mathrm{~m}, 30 \times 30 \mathrm{~m}$ and $40 \times 40 \mathrm{~m}$. The Grad601 instrument is 
usually carried by an operator and used to detect magnetic anomalies to $1.5 \mathrm{~m}$ beneath a land surface. The produced magnetic anomaly maps are then examined to detect anomaly groups that may result from ground disturbance by past human activities. The profiles were separated from each other at distance of $0.5 \mathrm{~m}$. The version of the TerraSurveyer software dedicated especially to Grad601 instrument was used in the processing.

\section{RESULTS}

The Lopar archaeological site is located in a protected natural reserve and for this reason we could examine a few limited areas only that were not dense vegetated. Five study areas for geophysical surveys were selected and numbered from 1 to 5 (Fig. 3): three in the vicinity of a stone structure and the other two on terraces near a shoreline (Figs 6-7).

The traverse no. $1(20 \times 20 \mathrm{~m})$ is set directly to the north of the so-called stone structure. The entire area is at present densely overgrown by grass, trees and bushes with small concentrations of stone low walls of N-S and S-E orientation (Figs 3, 6-7). The stone structure is composed of loose limestone blocks of varied size without a mortar (Fig. 7). Two measurement zones (nos. 1-2) were set within this feature and magnetic, GPR and ERT surveys were conducted within its boundaries (Fig. 3).

The map of magnetic anomalies obtained by gradiometer in the area no. 1 does not reveal a presence of anthropogenic structures, except of these visible on the land surface (Fig. 8A). Results of a magnetic survey were confirmed by GPR measurements. GPR anomaly maps (depth slices) at selected depth i.e. 0.0, 0.25, 0.5 and $0.75 \mathrm{~m}$ did not reveal underground anthropogenic features, except of ground stone walls (Fig. 8B). A definitive confirmation of the thesis that the study area lacks any underground anthropogenic structures came from ERT application. Analysis of resistivity distribution of the measured ERT profile oriented northsouth and its relation to the stone exposures noted in the field enabled to distinguish two geoelectrical horizons (Fig. $8 \mathrm{C})$. They correspond to subsurface soil layer $(90 \Omega \mathrm{m}$ to $1000 \Omega \mathrm{m})$ and Paleogene sandstone bedrock ( 0 to $90 \Omega \mathrm{m})$.

The area no. 2 was located within the stone structure (Figs 3, 6, 9) with NW-SE orientation and dimensions of $20 \times 10$. Gradiometer measurements have revealed a series of strong positive anomalies (0-11 nT) directly below a land surface, which should be interpreted as shallow buried walls or more probably, the foundation trenches. They mark clearly a fragment of a regular structure with longer walls running NW-SE (Fig. 9B). Results of magnetic measurements were supplemented by GPR profiling. GPR depth slices were set at $0.1 \mathrm{~m}, 0.25 \mathrm{~m}$ and $0.5 \mathrm{~m}$ depth (Fig. 9B). They reveal presence of anomalies with spatial orientation different than recorded with magnetic survey (Fig. 10). A comparison of magnetic plans with GPR amplitude maps is very useful, because both methods produce images of different buried construction materials. GPR reflection is usually produced by 'real' i.e. physical remains, for instance

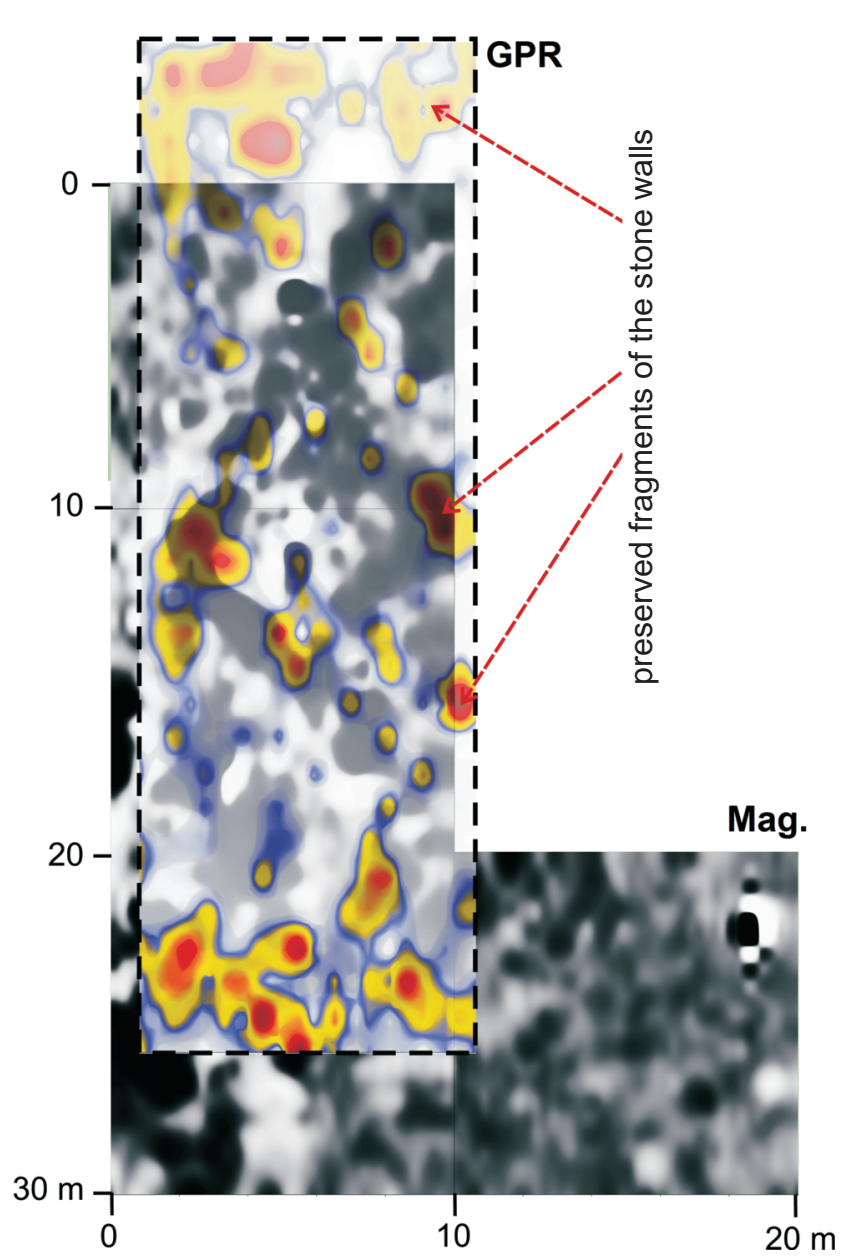

Fig. 10. Comparison between magnetic and GPR data at the site no. 2 at Lopar (A).

by stone building foundations (this is due to reflection of electromagnetic waves from underground objects and lithological boundaries). In contrast, magnetic anomaly maps present usually concentration of ferromagnetic minerals which effect the Earth magnetic field intensity, such as destruction layers (ashes), firing places and furnaces, infillings of the moats and trenches or foundation trenches even if there are no physical remains of the walls inside (Conyers, 2013, 2016). Based on this, we can assume that in the case of the area no. 2, a magnetic plan enables to trace the walls, even they have not survived. It is why we are not able to say anything about the real state of preservation of located ancient structures (Fig. 9A). In contrast, GPR depth slices present physical building remains, most probably composed of stones which are visible as sets of characteristic anomalies on reflection profiles and depth plans (Figs 9B, 10).

Results of magnetic and GPR surveys are confirmed by ERT soundings. Accordingly, $39 \mathrm{~m}$ long profile was obtained in the area no. 2, revealing two distinctive geoelectrical horizons. The horizon 1 corresponds to a subsurface soil layer and underlying archaeological remains, characterized by resistivity from over 90 to $300 \Omega \mathrm{m}$. This horizon occurs at $0.0-0.6 \mathrm{~m}$ depth and corresponds to results of GPR and magnetic measurements, confirming presence of anthropo- 


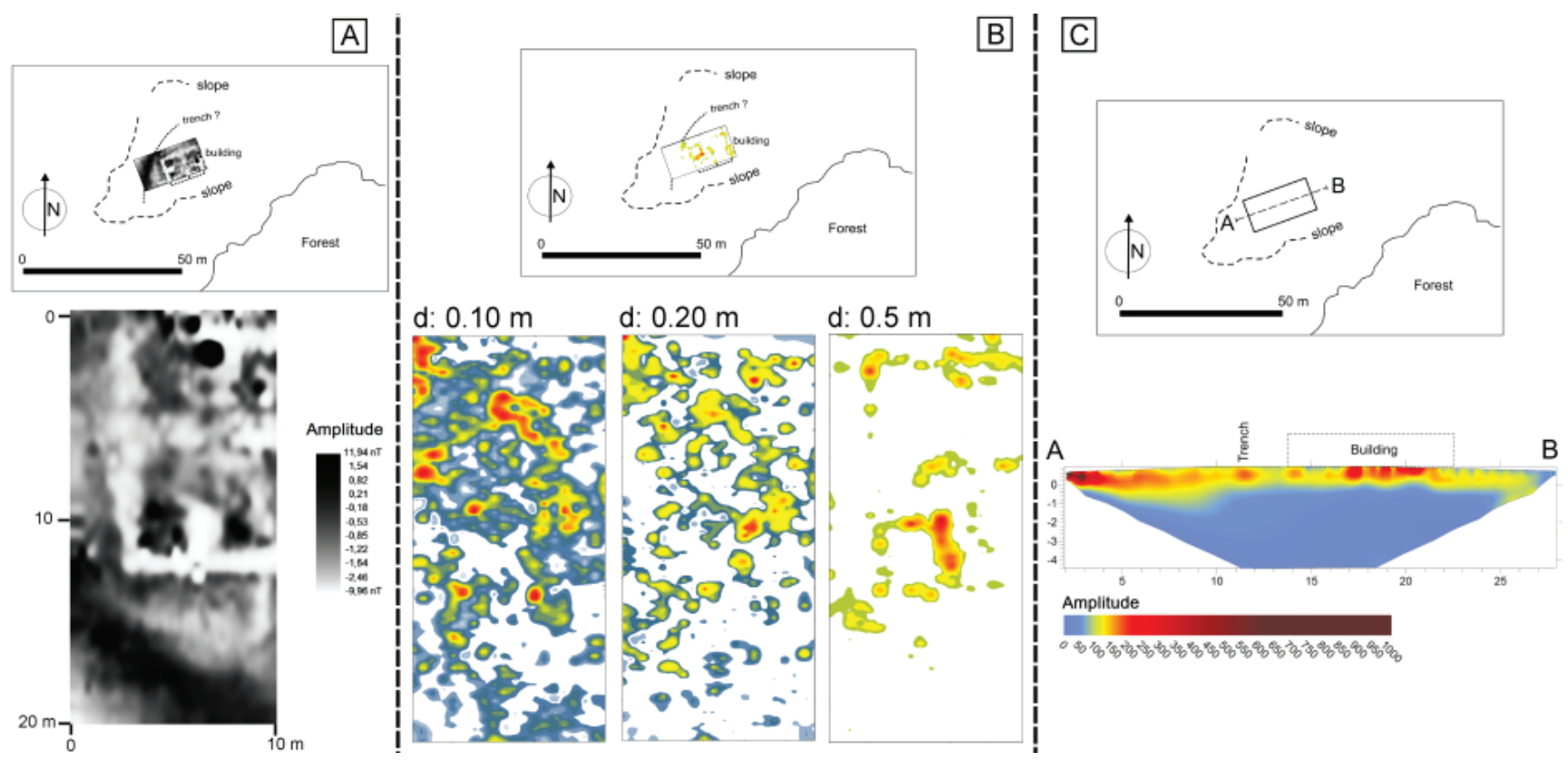

Fig. 11. Results of the geophysical survey at the site no. 4, area no. 2. A-magnetic, B - GPR, C - ERT.

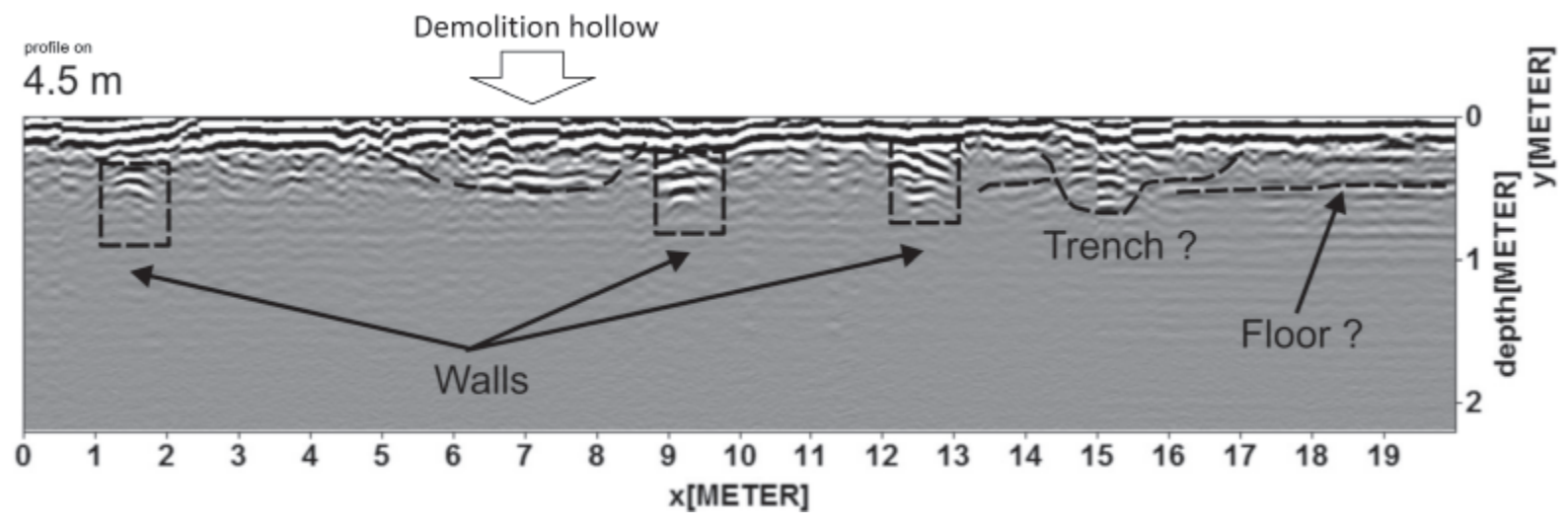

Fig. 12. Interpretation of the reflection profile no. 9 in the area no. 4.

genic underground features, especially at distances $0-15 \mathrm{~m}$ and $25-35 \mathrm{~m}$ of the profile A-B. The horizon 2 corresponds to the Paleogene bedrock (sandstone) and is characterized by electrical resistivity of $0-90 \Omega \mathrm{m}$ (Fig. 9C).

The area no. 3 is located about $100 \mathrm{~m}$ to the south-west of the stone structure. It is $10 \times 10 \mathrm{~m}$ large, covered by sandy packets deposited by a flowing water. A magnetic survey did not reveal presence of any structures that could be connected with intentional human activity (Fig. 2).

The most interesting results were collected in the area no. 2 which was located on a small terrace at a southern side of an erosional valley (Figs 3, 6, 11). Small escarpments in the north and west, indicated by soil creeping and intensive erosional processes, delimit the area. The measurement polygon is $30 \times 10 \mathrm{~m}$ large and oriented NE-SW. Gradiometer measurements revealed a number of strong magnetic anomalies below a land surface, generated by remains of a sub-rectangular building ca. $15 \times 12 \mathrm{~m}$ in size, with the interior subdivided by transverse walls into smaller chambers (Fig. 11A). The building is oriented westeast. In the western part, about $1 \mathrm{~m}$ from the western wall of the building, a wide anomaly zone with high amplitudes occurred, significantly contrasting with the surroundings. It can be primarily interpreted as a shallow trench running north-south. Outlines of the building are mostly indicated by negative magnetic anomalies, what suggests presence of a limestone, resulting in a strong magnetic contrast against the surrounding sandy clay with a substantial admixture of iron minerals (see description of the drilling LOPAR 1).

Results of magnetic measurements in the same area were supplemented by GPR survey. GPR plans elaborated at the depth interval $0.4-0.6 \mathrm{~m}$ reveal presence of numerous anomalies concentrated in the eastern part of the study area (Fig. 11B). GPR depth slice at $0.4 \mathrm{~m}$ depth clearly reveals an outline of a square building. Analysis of reflection profiles indicate where wall remains are preserved, visible as series 


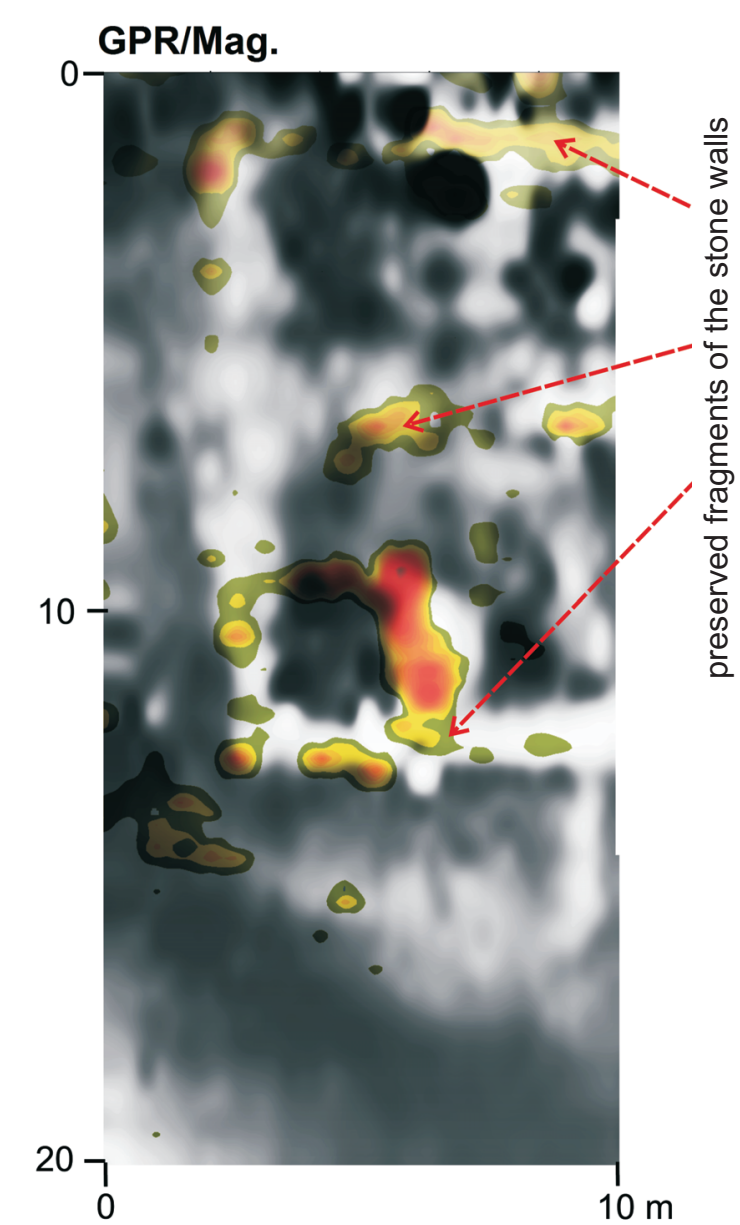

Fig. 13. Comparison between magnetic and GPR data at the site 3 at Lopar.

of diffraction hyperboles. They also reveal a trench, $0.6 \mathrm{~m}$ deep. Moreover, GPR profiles indicate also a shallow hollow, which should be probably connected with a younger, demolished building (Fig. 12).

The electrical resistivity sounding was conducted in the area no. 4 along its SW-NE axis (Fig. 11C). The ERT profile was $26 \mathrm{~m}$ long. It reveals two distinct geoelectrical horizons. The horizon 1 corresponds to subsurface archaeological remains and is characterized by resistivity of 90-1000 $\Omega \mathrm{m}$. The horizon 2 corresponds to the Paleogene bedrock and is characterized by resistivity of $0-90 \Omega \mathrm{m}$ (Fig. 11C). Generally magnetic, GPR and ERT surveys conducted in the area no. 4 reveal presence of a sub-rectangular architectural structure with wall remains at $0.4-0.6 \mathrm{~m}$ depth. In the western part of the study area a shallow trench (or small slope) running north-south was recorded. As in the case of the area no. 2, we can assume that a magnetic plan allows tracing the walls even if they have not survived. GPR depth slices present physical remains of the building composed of limestone blocks as confirmed by the drilling LOPAR 1 (Fig. 13).

The area no. 5 is ca. $20 \times 20 \mathrm{~m}$ and was located on a low terrace several meters from a sea coast (Fig. 2). There are small stone blocks in the center, partly preserved on the surface and probably representing remains of an an- cient building wall (Fig. 6). Magnetic measurements revealed presence of a bimodal anomaly distribution below the land surface. It subdivides the study area into two zones, a southern one with low amplitude of recorded anomalies and a northern zone with much higher amplitude (Figs 3, 6, 14A). The boundary between these zones corresponds to the stone wall preserved on the surface. Additional data were supplied by GPR survey (Fig. 14B). A quasi 3D block-diagram revealed a distinct reflection horizon occurring in the southern part of the study area, which may be interpreted as a vast depression filled with anthropogenic sediments (horizontal reflections). Diffraction hyperboles at depth of $0.3 \mathrm{~m}$ are most probably generated by remains of a wall running SW-NE across the study area. Collected data suggest that a southern part of the study area is covered by remains of an ancient building, interior of which is filled with rubble (most probably created during demolition). Geophysical data are supplemented by shallow drillings LOPAR 2 and LOPAR 3 in southern and northern parts of the studied area. The first drilling revealed presence of a thick anthropogenic layer at depth $0.05-0.70 \mathrm{~m}$ composed of coarse-grained sand with silt, charcoal and small fragments of mortar. In the northern part of the study area coarse sand and sand with silt (native soil) occur at the same depth only (Fig. 5).

\section{CONCLUSIONS}

Summing up, geophysical studies conducted in the Lopar area in the north-eastern part of the Island of Rab revealed underground remains of ancient structures, probably from the late Roman period and possibly connected with a ceramic production center discovered near the present seashore. GPR, ERT and magnetic measurements in the area no. 1 (directly to the north of the so-called stone structure) were negative, because no anthropogenic buried structures were found, except for these still visible on the land surface. In contrast, in the area no. 2, an anthropogenic structure was located. Its regular outline and depth (ca. $0.5 \mathrm{~m}$ ) suggest that it pre-dates the so-called stone structure preserved on the land surface.

The most interesting results were obtained in the area no. 4 site where magnetic, GPR and ERT surveys revealed presence of a regular ancient building, preserved at of 0.4$0.6 \mathrm{~m}$ depth. Additionally, a shallow north-south oriented trench (or slope) was located in the western part of the area. Its relation to the building can be explained by archaeological excavations only.

In the area no. 5 geophysical surveys indicated presence of a very poorly preserved building filled most probably with a rubble (due to demolition). A northern margin (wall?) of this structure corresponds to remains of a stone wall still visible on the land surface.

The survey in the Lopar area clearly indicates that integration of different geophysical methods allows detailed and effective identification of buried archaeological structures. Integration of magnetic, GPR and ERT methods provides mutually consistent results, but in some cases gives 


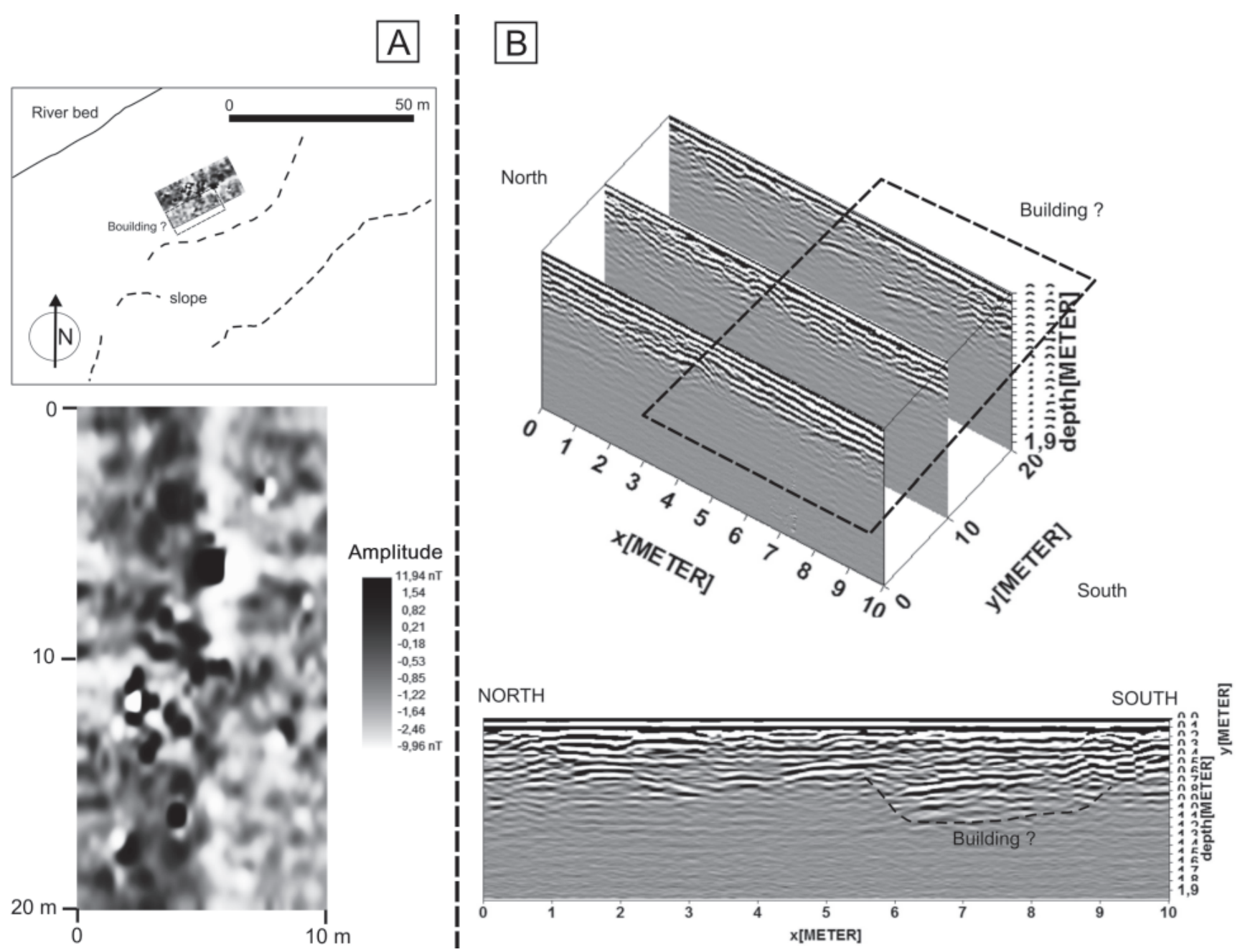

Fig. 14. Results of the geophysical survey at the site no. 5, area no. 2. A-magnetic, B - GPR, C - ERT.

also complementary information, especially when comparing magnetic and GPR data (Figs 10 and 13). On maps with magnetic anomalies buried walls and foundation remains can be traced, but not all of them are visible on GPR depth slices. In opposite, magnetic data do not deliver information about the depth and vertical cross-sections of recognized anomalies. Such information is supplied by the GPR records (Figs 10 and 13). It is among the most important advantages of this method and allows preparing 3D time slices (GPR maps) of underground structures at various depths without excavation (Conyers, 2013, 2016a).

A comparison of magnetic maps with GPR amplitude maps is very important, because these two methods produce images of different buried construction materials. The GPR reflection was produced by real (physical) remains of stone building foundations or by demolition layers. In contrast, magnetic anomaly maps present different materials, mostly with large concentration of ferromagnetic minerals such as destruction layers (concentration of ashes), firing places, furnaces, infillings of the moats and trenches, remains of walls or foundation trenches. In the case of the area 4, GPR depth slices present building remains composed of stone material only, which generate GPR anoma- lies. The rest of the building is visible only on a magnetic map. This method allows tracing remains of walls even if they have not survived, because outlines of wall trenches (negatives) are traced as filled with slightly different material than in a surrounding area.

Integration of GPR and ERT is also quite apparent. For example GPR reflection profiles and ERT section in the area no. 4 (Fig. 11) are in good agreement and prove presence of a large building characterized by higher resistivity (ERT) and low attenuation of EM wave (GPR), what is characteristic for materials in buried walls or wall foundations (limestone mortar).

This study indicates that compilation and integration of magnetic, GPR and ERT is extremely important, as both are creating images of different buried materials. Finally, application of multiple methods should be a standard procedure in geophysical surveys. Not only it increases a chance for successful research, but it can greatly enhance interpretability of results, because each geophysical method responds to different properties and geological structure of the examined site.

The presented results of a geophysical survey at the Lopar site confirmed presence of remains of ancient buildings in 
the areas nos. 2, 4 and 5. Such stratigraphic distribution indicates that these structures can be dated to the Roman Period or the Late Antiquity. Because just remains of foundations survived, they suggest that the so-called stone structure was built from re-used material, derived from demolition of antique buildings in the Lopar area. Thus, it should be dated to a much younger period (Middle Ages?).

\section{Acknowledgments}

The authors would like to thank Professor L. Conyers (Department of Anthropology, University of Denver, USA) and Dr. K. ZemanWiśniewska (Institute of Archaeology, Cardinal Stefan Wyszyński University in Warsaw, Poland) for reviewing the manuscript and many constructive comments and suggestions.

\section{REFERENCES}

Aspinall, A., Gaffney, C.F., Schmidt, A., 2008. Magnetometry for Archaeologists. Plymouth Altamira Press, Lanham. New York, Toronto.

Brizzolari, E., Ermolli, F., Orlando, L., Piro, S., Versino, L., 1992. Integrated geophysical methods in archaeological surveys. Journal of Applied Geophysics 29, 47-55.

Cardarelli, E., Di Filippo, G., 2009. Integrated geophysical methods for the characterization of an archaeological site (Massenzio Basilica - Roman forum, Rome. Italy). Journal of Applied Geophysics 68 (4), 508-521.

Conyers, B.L., 2010. Ground-Penetrating Radar for anthropological research. Antiquity 84, 1-11.

Conyers, B.L., 2013. Ground-Penetrating Radar for Archaeology. 3rd Edition. Altamira Press.

Conyers, B.L., 2016. Ground-Penetrating Radar for Geoarchaeology. Wiley Blackwell.

Conyers, B.L., 2016a. Ground-Penetrating Radar Mapping Using Multiple Processing and Interpretation Methods. Remote Sensing 8, 562: doi:10.3390/rs8070562

Conyers, B.L., Leckebusch, J., 2010. Geophysical archaeology research agendas for the future: Some Ground-Penetrating Radar examples. Archaeological Prospection 17, 117-123.

Cozzolino, E., Di Giovanni, P., Mauriello, A., Desideri, D.P., 2012. Resistivity Tomography in the Park of Pratolino at Vaglia (Florence, Italy). Archaeological Prospection 19, 253-260.

De Domenico, D., Giannino, F., Leucci, G., Bottari, C., 2006. Integrated geophysical surveys at the archaeological site of Tindari (Sicily, Italy). Journal of Archaeological Sciences 33 (7), 961-970.

Di Maio, R.L.A., Manna, M., Piegari, E., 2016. 3D Reconstruction of Buried Structures from Magnetic, Electromagnetic and ERT Data: Example from the Archaeological Site of Phaistos (Crete, Greece). Archaeological Prospection 23, 3-13.

Drahor, M.G., 2006. Integrated geophysical studies in the upper part of Sardis archaeological site, Turkey. Journal of Applied Geophysics 59 (3), 205-223.

Drahor, M.G., Berge, M.A., Oztruk, C., Alpaslan, N., Ergne, G., 2009. Integrated usage of geophysical prospection techniques in Höyük (tepe, tell)-type archaeological settlements. ArcheoSciences 33, 291-294.

Drahor, M.G., Göktürkler, G., Berge, M.A., Kurtulmus, T.Ö., Tuna, N., 2007. 3D resistivity imaging from an archaeological site in south-western Anatolia, Turkey: A case study. Near Surface Geophysics 5, 195-201.

Drahor, M.G., Kaya, M.A., 2000. A large Scale Geophysical Prospec- tion in Acemhöyük, the site of the Assyrian Trade Colony Period. Turkish Academy of Sciences Journal of Archaeology 3, 85-107.

Fassbinder, W.E., 2015. Seeing beneath the farmland, steppe and desert soil: magnetic prospecting and soil magnetism. Journal of Archaeological Science 56, 85-95.

Gaffney, C.F., 2008. Detecting trends in the prediction of the buried past: a review of geophysical techniques in archaeology. Archaeometry 50 (2), 313-336.

Gaffney, C.F., Gater, J.A., Linford, P.K., Gaffney, V.L., White, R., 2000. Large scale systematic fluxgate gradiometry at the Roman City of Wroxeter. Archaeological Prospection 7, 81-99.

Gaffney, V., Patterson, H., Prio, S., Goodman, D., Nishimura, Y., 2004. Multimethodological approach to study and characterize Forum Novum (Vescovio, Central Italy). Archaeological Prospection 11, 201-212.

Griffiths, D.H., Barker, R.D., 1993. Two-dimensional resistivity imaging and modelling in areas of complex geology. Journal of Applied Geophysics 29, 211-226.

Herbich, T., 2003. Archaeological geophysics in Egypt: the Polish contribution. Archaeologia Polona 41, 13-56.

Herbich, T., 2012. Geophysical methods and landscape archaeology. Egyptian Archaeology 41, 11-14.

Herman, R., 2001. An introduction to electrical resistivity in geophysics. American Journal of Physics 69 (9), 943-952.

Herwanger, J.H., Maurer, A.G., Green, J., Leckebusch., 2000. 3-D inversions of magnetic gradiometer data in archaeological prospecting: Possibilities and limitations. Geophysics 65(3), 849-860.

Jordan, D., 2009. How effective is geophysical Survey? A regional review. Archaeological Prospection 16, 77-90.

Jurković, M., Brogiolo, G.P., Turković, T., Chavarria, A.A, Marić, I., 2012. Kaštelina na otoku Rabu: od rimskevile do ranobizantskeutvrde. Rabski zbornik 2, 1-14 (in Croatian).

Kattenberg, A.E., Aalbersberg, G., 2004. Archaeological prospection of the Dutch perimarine landscape by means of magnetic methods. Archaeological Prospection 11 (4), 227-235.

Keay, S., Earl, G., Hay, S., Kay, S., Ogden, J., Strutt, K.D., 2009. The Role of Integrated Geophysical Survey Methods in the Assessment of Archaeological Landscapes: the Case of Portus. Archaeological Prospection 16, 154-166.

Keller, G.V, Frischknecht, F.C., 1966. Electrical methods in geophysical prospecting. Pergamon Press, Oxford.

Kvamme, K., 2006. Integrating multi-dimensional geophysical data. Archaeological Prospection 13, 57-72.

Leucci, G., Greco, F., 2012. 3D ERT Survey to Reconstruct Archaeological Features in the Subsoil of the "Spirito Santo" Church Ruins at the Site of Occhiolà (Sicily, Italy). Archaeology 1 (1), 1-6.

Leucci, G., Masini, N., Rizzo, E., Capozzoli, L., De Martino, G., De Giorgi, L., Marzo, C., Roubis, D., Sogliani, F., 2015. Integrated Archaeogeophysical Approach for the Study of a Medieval Monastic Settlement in Basilicata. Open Archaeology 1, 236-246.

Lipovac, G.V., Bartul, V., Ivana, Š., Roguljić, O., Konestra, A., Kostešić, I., Šegvić, N., 2014. The "Archaeological Topography of the Island of Rab" Project: the results of the 2013 field survey of the Lopar Peninsula. Annales Instituti Archaeologici 10, 202-208.

Lipovac, G.V., Bartul, V., Music, B., Siljeg, B., Konestra, A., 2015. Geophysical Survey of ancient structures in MahućIna Bay on the Island of Rab (Lopar municipality), 2014 (HRZZ, Croatian Science Fundation Project RED). Annales Instituti Archaeologici 11, 80-82.

Lipovac, G.V., Konestra, A., 2015. Project Archaeological topography of the Island of Rab - results of field survey in the City of Rab area in 2014 and exhibition Archaeological topography: a journey through the history of Lopar. Annales Instituti Archaeologici 11, 128-134.

Lipovac, G.V, Šiljeg, B., 2012. Contribution to the Ancient Topography of the Island of Rab - Roman Ceramist's Kiln in Lopar. Senjskizbornik 39, 5-33. 
Loke, M.H., Barker, R.D., 1996. Rapid least-squares inversion of apparent resistivity pseudosections by a quasi-Newton method. Geophysical Prospecting 44, 131-152.

Luck, E., Callmer, J., Skanberg, T., 2003. The House of the Bailiff of Sovestad, Sweden - a Multi-method Geophysical Case Study. Archaeological Prospection 10, 143-151.

Malez, M., 1987. Geološki, paleontološki i prethistorijski odnosi otoka Raba. Rapskizbornik 1, 141-146 (in Croatian).

Mamuzić, P., Milan, A., Korolija, B., Borović, I., Majcen, Ż., 1969. Geological Map 1:100,000, Sheet Rab. Federal Geol. Inst., Belgrade.

Marjanac, T., Marjanac, L., 1991. Shallow-marine clastic Paleogene on the Island of Rab (Northern Adriatic). Abstracts Dolomieu Conference on Carbonate Platforms and Dolomitization. Ortisei, 159-160.

Marjanac, T., Marjanac, L., 2007. Sequence stratigraphy of Eocene incised valley clastics and associated sediments, Island of Rab, Northern Adriatic Sea, Croatia. Facies 53, 493-508.

Marjanc, T., Marjanac, L., 2016. The extent of middle Pleistocene ice cap in the coastal Dinaric Mountains of Croatia. Quaternary Research 85 (3), 445-455.

Milsom, J., 2003. Field Geophysics. 3rd Edition. Wiley.

Mol, L., Preston, P., 2010. The writing's in the wall: A review of new preliminary applications of electrical resistivity tomography within archaeology. Archaeometry 52 (6), 1079-1095.

Neubauer, W., Eder-Hinterleitner, A., 1997. 3D-interpretation of post-processed archaeological magnetic prospection data. Archaeological Prospection 4, 191-205.

Neubauer W., Eder-Hinterleitner, A., 1997a. Resistivity and magnetics of the Roman town of Carnuntum, Austria: an example of combined interpretation of prospection data. Archaeological Prospection 4, 179-189.

Owsin, J.A., 2009. Field guide to geophysics in archaeology. Springer.

Papadopoulos, N.G., Sarris, A., Parkinson, W.A., Gyucha, A, Yerkes, R.W., Duffy, P.R., Tsourlos, P., 2014. Electrical resistivity tomography for the modelling of cultural deposits and geomorphological landscapes at Neolithic sites: A case study from southeastern Hungary. Archaeological Prospection 21, 169-183.

Papadopoulos, N.G., Tsourlos, P., Papazachos, C., Tsokas, G.N., Sarris, A., Kim, J.H., 2011. An Algorithm for the Fast 3-D Resistivity Inversion of Surface Electrical Resistivity Data: Application on Imaging Buried Antiquities. Geophysical Prospection 59, 557-575.

Piro, S., Mauriello, P., Cammarano, F., 2000. Quantitative integration of geophysical methods for archaeological prospection. Archaeological Prospection 7, 203-213.

Sasaki, Y. 1992. Resolution of resistivity tomography inferred from numerical simulation. Geophysical Prospecting 40, 453-464.

Scollar, I., Tabbagh, A., Hesse, A., Herzog, I., 1990. Archaeological Prospecting and Remote Sensing. Topics in Remote Sensing 2. Cambridge University Press, Cambridge.

Strutt, K., Keay, S., 2008. The role of integrated geophysical survey methods in the assessment of archaeological landscapes: the case of Portus. Archaeological Prospection 16, 154-166.

Thacker, P.T., Ellwood, B.B., 2002. Detecting palaeolithic activity areas through electrical resistivity survey: an assessment from Vale de Obidos, Portugal. Journal of Archaeological Science 29, 563-570.

Toushmalani, R., 2010. Application and Limitation of Geophysical Techniques in Archaeology. Australian Journal of Basic and Applied Sciences 4 (12), 6440-6449.

Vermeulen, F., Hay, S., Verhoeven, S. 2006. Potentia: an integrated survey of a Roman colony on the Adriatic coast. Papers of the British School at Rome 74, 203-236.

Vlahović, I., Tišljar, J., Velić, I., Matičec, D. 2005. Evolution of the Adriatic Carbonate Platform: Palaeogeography, main events and depositional dynamics. Palaeo 220, 333-360.

Weymouth, J.W., 1986. Geophysical methods of archaeological site surveying. Advances in Archaeological Method and Theory 9, 370-382.

Won, I.J., Huang, H., 2004. Magnetometers and electromagnetometers. The Leading Edge 23, 448-451.

Zhdanov, M.S., Keller, G.V., 1994. The geoelectrical methods in geophysical exploration. Elsevier. Amsterdam. 